\title{
Analisis Kuantitatif Hidrokuinon pada Produk Kosmetik Krim Pemutih yang Beredar di Wilayah Surabaya Pusat dan Surabaya Utara dengan Metode Spektrofotometri UV-Vis
}

\author{
Arifiyana, D. ${ }^{1}$; Harjanti, Y. S. ${ }^{1}$; Ebtavanny, T. G. ${ }^{2}$ \\ ${ }^{1}$ Akademi Farmasi Surabaya. Jl. Ketintang Madya No. 81 Surabaya-60231, Jawa Timur \\ ${ }^{2}$ Universitas Brawijaya. Jl. Veteran Malang - 65145, Jawa Timur
}

${ }^{*}$ Corresponding author:

\begin{abstract}
Hydroquinone is an active compound capable of controlling pigment production, which serves to reduce or inhibit the formation of melanin in the skin. This causes makes hydroquinone often to be used as bleach in creams. In this study a quantitative analysis of hydroquinone was carried out in facial whitening cream cosmetic products circulating in Central Surabaya and North Surabaya, both those with BPOM registration numbers and those who did not have BPOM registration numbers. The sample in this study amounted to 12 samples consisting of 6 samples of whitening cream which had a BPOM registration number with codes $A, B, C, D, E, F$ and 6 types of whitening creams that did not have a BPOM registration number with code $G, H, I, J, K, L$. Analysis was carried out by $U V$-Vis spectrophotometry method. The results showed that the highest levels of hydroquinone were obtained from sample $G$ with the acquisition of hydroquinone levels of $0.0331 \%$, and overall hydroquinone levels in the samples used in this study did not exceed the limit of hydroquinone levels set by BPOM, with no more than $2 \%$.
\end{abstract}

Keywords: Hydroquinone, Whitening Cream, Spectrophotometry UV-Vis.

\begin{abstract}
Abstrak
Hidrokuinon merupakan senyawa aktif yang mampu mengendalikan produksi pigmen, yakni berfungsi untuk mengurangi atau menghambat pembentukan melanin kulit. Hal inilah yang menyebabkan hidrokuinon sering kali digunakan sebagai pemutih dalam krim. Pada penelitian ini dilakukan analisis kuantitatif hidrokuinon dalam produk kosmetik krim pemutih wajah yang beredar di wilayah Surabaya Pusat dan Surabaya Utara, baik yang memiliki nomor registrasi BPOM maupun yang tidak memiliki nomor registrasi BPOM. Sampel dalam penelitian ini berjumlah 12 sampel yang terdiri dari 6 sampel krim pemutih yang memiliki nomor registrasi BPOM dengan kode $A, B, C, D, E, F$ dan 6 jenis krim pemutih yang tidak memiliki nomor registrasi BPOM dengan kode $G, H, I, J, K, L$. Analisis dilakukan dengan metode spektrofotometri UV-Vis. Hasil penelitian menunjukkan bahwa kadar tertinggi hidrokuinon
\end{abstract}


diperoleh dari sampel $G$ dengan perolehan kadar hidrokuinon sebesar 0,0331\%, dan secara keseluruhan kadar hidrokuinon pada sampel yang digunakan dalam penelitian ini tidak melebihi batas kadar hidrokuinon yang ditetapkan BPOM, yaitu tidak lebih dari $2 \%$.

Keywords: Hydroquinone, Whitening Cream, Spectrophotometry UV-Vis.

\section{Pendahuluan}

Kosmetik secara umum saat ini seakan telah menjadi kebutuhan primer. Kebutuhan akan kosmetik ini tidak hanya diperuntukkan bagi wanita, bahkan saat ini pria pun telah menjadi konsumen kosmetik. Industri kosmetik saat ini umumnya tidak hanya terbatas memproduksi satu jenis produk kosmetik saja (bedak, minyak rambut dan obat jerawat), namun meluas hingga semua jenis kosmetik yang ditujukan kepada semua segmentasi pasar, yakni mulai dari kalangan bawah hingga atas, diberbagai usia mulai bayi, remaja hingga dewasa [1]. Kosmetik sendiri pada dasarnya merupakan sediaan yang diaplikasikan pada tubuh dengan tujuan untuk membersihkan dan memperbaiki penampilan. Semakin meningkatnya populasi penduduk maka dapat dikaitkan dengan meningkatnya tingkat konsumsi manusianya, tidak terkecuali konsumsi kosmetika [2]. Surabaya selain merupakan ibukota propinsi Jawa Timur, juga sebagai kota terbesar kedua di Indonesia setelah Jakarta memiliki populasi penduduk sekitar tiga juta orang.
Populasi ini terus bertambah seiring dengan berjalannya waktu. Saat ini Surabaya juga telah menjadi sentra industri, perdagangan, bisnis, dan pendidikan di Indonesia. Surabaya terbagi menjadi beberapa wilayah, meliputi Surabaya Pusat, Utara, Selatan, Timur dan Barat. Diantara kelima wilayah ini Surabaya Pusat dan Utara merupakan wilayah dengan sentra dagang tradisional yang lebih banyak dengan tingkat kunjungan yang tinggi. Dimana sentra dagang di Surabaya Pusat meliputi Surabaya Pusat (Pasar Blauran, Pasar Kapasan, dan Pasar Wonorejo) dan pasar di wilayah Surabaya Utara (Pasar Pegirian, Pasar Kedung Cowek, dan Pasar Tambakwedi).

Populasi yang tinggi menyebabkan perkembangan tren kosmetika mudah tersebar secara cepat. Salah satu tren kosmetika saat ini adalah kosmetika krim pemutih wajah. Wajah yang putih atau cerah saat ini seakan menjadi tolak ukur kecantikan dan memiliki keuntungan tersendiri. Perspektif kulit cerah sebagai simbol kecantikan dianggap sebagai standar 
di seluruh dunia, utamanya di negara-negara yang sebelumnya dijajah oleh Eropa atau negara dengan tingkat kunjungan warga negara Amerika Serikat yang tinggi [3, 4]. Hal ini menyebabkan produksi produk kosmetik pemutih kulit terus meningkat dan termasuk kedalam permintaan tinggi di dunia [5]. Hal ini kemungkinan merupakan cerminan dari keuntungan sosial yang dirasakan (misalnya dalam hal pekerjaan dan prospek perkawinan yang lebih baik) yang terkait dengan warna kulit yang lebih terang di beberapa wilayah atau negara [6]. Dahulu, produk sintetis tidak tersedia dan orang menggunakan produk alami seperti daun mint, almond, madu, lemon, kentang, dan kulit jeruk. Dalam praktik dermatologis, agen depigmentasi digunakan oleh banyak ahli dermatologi dengan baik dan rutin untuk mengobati gangguan hiperpigmentasi (misalnya hiperpigmentasi melasma dan pasca-inflamasi), yang biasanya terjadi pada individu dengan kulit berpigmen atau sebagai tren fesyen yang mengurangi pigmen melanin normal pada kulit [7, 8].

Hidrokuinon merupakan suatu zat yang efektif terhadap pemutih kulit namun mempunyai efek samping merusak jika digunakan dalam jangka panjang. Dokter kulit di beberapa negara merekomendasikan penggunaan hidrokuinon pada konsentrasi sebesar 2\%, namun di beberapa negara lainnya merekomendasikan hingga konsentrasi $4 \%$. Untuk penggunaan harian bisa digunakan tidak lebih dari 6 bulan [9]. Hidrokuinon pada dasarnya tidak bekerja sebagai pemutih kulit, namun menghambat produksi melanin [10].

Penggunaan bahan hidrokuinon pada kulit sangat berbahaya. Hidrokuinon merupakan senyawa yang berpotensial bersifat karsinogenik [11]. Hidrokuinon yang digunakan untuk aplikasi topikal diketahui dapat menyebabkan bahaya yang serius terhadap kesehatan bila digunakan secara berlebihan [12], efek samping yang paling sering timbul yaitu rasa terbakar pada kulit, perasaan gatal, iritasi, pigmentasi, gangguan di area telinga, jari, sendi-sendi jari, sehingga perlu dilakukan observasi untuk penggunaan dalam jangka panjang [9]. Toksisitas hidrokuinon dapat menyebabkan efek samping yang serius, meliputi keracunan darah, mual, sakit perut, kejang, kerusakan hati dan ginjal, dan bahkan koma. Uji toksisitas hidrokuinon terhadap hewan coba mencit, tikus dan kelinci menunjukkan bahwa hidrokuinon dapat menyebabkan toksisitas akut [13].

Pada tahun 2006 dan 2007 BPOM RI melakukan investigasi dan pengujian laboratorium terhadap kosmetik, ditemukan 
sebanyak 23 produk kecantikan yang didalamnya mengandung spesi terlarang untuk digunakan dalam sediaan kosmetik kecantikan, dimana satu diantaranya merupakan adanya penggunaan hidrokuinon dengan persentase $>2 \%$ [14].

Penelitian mengenai analisis kandungan hidrokuinon pada krim pemutih wajah telah banyak dilakukan, beberapa diantaranya menggunakan spektrofotometri UV-Vis sebagai metode pengukurannya. Seperti pada penelitian yang dilakukan oleh Irnawati et al. yang mengambil sampel dari beberapa salon kecantikan yang terletak di Kecamatan Kendari Barat, Mandonga, Wua-Wua dan Kambu menggunakan spektrofotometer UV-Vis [15], Sarah pada sampel sediaan krim malam dari klinik kecantikan di Sidoarjo [16], Astuti et al. pada sediaan krim pemutih wajah yang beredar di minimarket wilayah Minomartani, Yogyakarta [17], serta Adriani dan Safira pada krim dari klinik kecantikan dokter di Banda Aceh [18], dimana penelitian-penelitian tersebut menggunakan spektrofotometer UV-Vis sebagai instrumen pengukurnya. Analisis hidrokuinon dengan instrumen pada dasarnya tidak hanya dapat dilakukan dengan spektrofotometri UV-Vis, beberapa penelitian menggunakan HPLC. Pada penelitian analisis hidrokuinon yang dilakukan oleh Agorku et al. [19] digunakan HPLC dilengkapi detector UV/visible dan fluorescence, penelitian dengan instrument serupa juga dilakukan oleh Htet et al. [20] dan Rahmayuni et al. [21]. Namun penggunaan HPLC ini memiliki kekurangan, yaitu penggunaannya yang relatif sulit, mahal dan membutuhkan beberapa jenis pelarut sebagai eluennya, serta diperlukannya optimasi kondisi untuk memperoleh hasil yang baik. Penggunaan spektrofotometri UV-Vis didasarkan atas kemudahan pengoperasiannya karena peralatan yang lebih sederhana, memiliki waktu analisis yang lebih singkat, dan lebih murah daripada teknik kromatografi [22], selain itu senyawa hidrokuinon memenuhi kriteria senyawa yang dapat dianalisis dengan spektrofotometri UV-Vis karena memiliki gugus kromofor [15]. Penggunaan Spektrofotometri UV-Vis telah meningkat pesat selama beberapa tahun terakhir. Beberapa keuntungan dari metode ini adalah presisi dan konsumsi reagen yang lebih sedikit [23]. Sehingga pada penelitian ini digunakan spektrofotometri UV-Vis.

\section{Metodologi Penelitian}

Penelitian ini dilakukan melalui beberapa tahapan yang meliputi pengambilan sampel krim, preparasi 
sampel, pembuatan larutan baku hidrokuinon, penentuan panjang gelombang maksimum, dan pengukuran kadar hidrokuinon pada sampel. Metode analisis kuantitatif pada penelitian ini diadopsi dari penelitian yang telah dilakukan oleh Irnawati et al. (2016) [15].

\section{Alat dan Bahan}

Alat-alat yang digunakan dalam penelitian ini adalah Spektrofotometer UVVis (Genesys 10S), neraca analitik (Denver, Ohaus), Labu ukur, kaca arloji, batang pengaduk, spatula, pipet tetes, gelas ukur, dan kertas saring. Bahan-bahan yang digunakan dalam penelitian ini adalah Standar Hidrokuinon (Medilux), Etanol 96\%, Metanol (Merck), aquadest.

\section{Pengambilan Sampel}

Sampel yang digunakan dalam penelitian ini merupakan sediaan kosmetik krim pemutih wajah dengan merk yang berbeda sebanyak 12 jenis yang diambil dari wilayah Surabaya Pusat dan Surabaya Utara, dimana 6 sampel memiliki nomor registrasi BPOM (Kode sampel A-F) dan 6 sampel lainnya tidak memiliki nomor registrasi BPOM (Kode sampel G-L). Sampel yang diambil dari wilayah Surabaya Pusat berasal dari Pasar Blauran, Pasar Kapasan, dan Pasar Wonorejo, sedangkan untuk wilayah Surabaya Utara berasal dari
Pasar Pegirian, Pasar Kedung Cowek, dan Pasar Tambakwedi. Sampel diambil dengan metode random sampling.

\section{Preparasi Sampel}

Preparasi sampel dilakukan melalui penimbangan masing-masing sampel krim pemutih sebanyak $25 \mathrm{mg}$ dan disuspensikan dalam metanol $50 \mathrm{~mL}$, kemudian dikocok sampai homogen.

\section{Pembuatan Larutan Baku Hidrokuinon}

Ditimbang standar hidrokuinon sebanyak $5 \mathrm{mg}$ dilarutkan dengan metanol, lalu dimasukkan dalam labu ukur $100 \mathrm{~mL}$ dan ditambahkan metanol sampai tepat 100 $\mathrm{mL}$, kemudian larutan dikocok sampai homogen. Sehingga didapatkan konsentrasi baku hidrokuinon 50 ppm dalam metanol. Dipipet $10 \mathrm{~mL}$ larutan baku $50 \mathrm{ppm}$ dimasukkan dalam labu ukur $50 \mathrm{~mL}$ tambahkan dengan larutan metanol hingga tepat $50 \mathrm{~mL}$ lalu dikocok hingga homogen. Didapatkan larutan dengan konsentrasi 10 ppm. Dipipet 0,$1 ; 0,2 ; 0,3 ; 0,4 ; 0,5 ; 1$; $1,5 \mathrm{~mL}$ dari larutan baku $10 \mathrm{ppm}$ masukkan masing-masing ke dalam labu ukur $50 \mathrm{~mL}$ tambahkan metanol sampai tanda. Didapatkan larutan dengan konsentrasi 0,02 ; 0,04;0,06;0,08;0,10;0,20;0,30 ppm. 


\section{Penentuan Panjang Gelombang} Maksimum

Dipipet $0,4 \mathrm{~mL}$ dari larutan baku 10 ppm masukkan dalam labu ukur $50 \mathrm{~mL}$, diencerkan dengan larutan metanol sampai tanda tera lalu dikocok hingga homogen dan dihasilkan larutan hidrokuinon dengan konsentrasi 0,08 ppm. Larutan 0,08 ppm diukur pada panjang gelombang 200-400 nm (dihasilkan pada panjang gelombang maksimum $293 \mathrm{~nm}$ ).

\section{Pengukuran Kadar Hidrokuinon Sampel}

Kadar hidrokuinon pada sampel dianalisis dengan spektrofotometri UV-Vis. Ukur absorbansi sampel secara spektrofotometri ultraviolet pada panjang gelombang $293 \mathrm{~nm}$. Sedangkan untuk menghitung kadar hidrokuinon dalam sampel dihitung dengan menggunakan persamaaan regresi linear : $y=b x \pm$ a yang diperoleh melalui kurva baku hidrokuinon.

\section{Hasil dan Pembahasan}

Sampel krim pemutih wajah sebanyak dua belas sampel yang diambil dari beberapa pasar di wilayah Surabaya Pusat (Pasar Blauran, Pasar Kapasan, dan Pasar Wonorejo) dan pasar di wilayah Surabaya Utara (Pasar Pegirian, Pasar Kedung Cowek, dan Pasar Tambakwedi) masingmasing diberi kode A, B, C, D, E, F, G, H,
I, J, K dan L. Sampel dipreparasi dengan methanol untuk selanjutnya dilakukan analisis kuantitatif dengan Spektrofotometer UV-Vis.

Larutan baku hidrokuinon disiapkan sebelum pengukuran sampel. Larutan baku hidrokuinon dibuat untuk digunakan pada penentuan panjang gelombang maksimum hidrokuinon dan pembuatan kurva baku hidrokuinon. Serangkaian larutan baku hidrokuinon dengan konsentrasi 0,02;0,04 ; 0,06;0,08;0,10;0,20;0,40 ppm dibuat, dimana dipilih larutan baku dengan konsentrasi 0,08 ppm sebagai larutan dalam penentuan panjang gelombang maksimum. Scanning penentuan panjang gelombang dilakukan pada rentang 200-400 nm dan diperoleh panjang gelombang maksimum hidrokuinon pada penelitian ini sebesar 293 nm. Hasil ini telah sesuai dengan penelitian yang dilakukan [15] yang memperoleh 293 nm sebagai panjangan gelombang maksimum untuk hidrokuinon.

Kurva baku hidrokuinon selanjutnya dibuat dengan mengukur absorbansi larutan baku hidrokuinon pada panjang gelombang maksimum yang telah diperoleh. Absorbansi (y) yang diperoleh kemudian diplot terhadap konsentrasi larutan baku (x). Kurva baku konsentrasi terhadap absorbansi membentuk garis lurus (linear) dan 
menghasilkan persamaan regresi linier $\mathrm{y}=2,8356+0,0018 \mathrm{x} \quad$ dengan koefisien korelasi $\left(\mathrm{R}^{2}\right)$ sebesar 0,9996. Penentuan kadar sampel metode regresi linier merupakan metode parametrik dengan variable bebas (konsentrasi sampel) dan variable terikat (absorbansi sampel) menggunakan persamaan persamaan garis regresi kurva larutan baku. Konsentrasi sampel dapat dihitung berdasarkan persamaan kurva baku yang diperoleh [24].

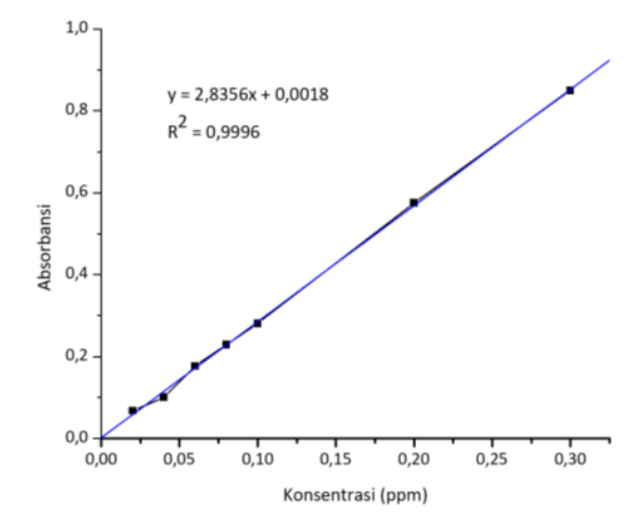

Gambar 1. Kurva Regresi Linier Standar Hidrokuinon

Penetapan kadar hidrokuinon dalam sampel krim pemutih wajah dilakukan dengan metode yang sama dengan pengukuran larutan baku, dimana larutan sampel yang telah dipreparasi diukur absorbansinya dengan Spektrofotometer UV-Vis pada panjang gelombang maksimum $293 \mathrm{~nm}$. Hasil pengukuran ditunjukkan pada Tabel 1 dan Gambar 2, diperoleh nilai absorbansi pada sampel dengan kode A, B, C, D, E, F, G, H, I, J, K dan L secara berturut-turut sebesar 0,079, $0,016,0,163,0,309,0,051,0,227,0,476$, $0,267,0,450,0,409,0,138$ dan 0,036 . Nilai absorbansi ini selanjutnya digunakan untuk menghitung konsentrasi yang kemudian dikonversikan kedalam bentuk persentase (\%) sehingga dapat dibandingkan dengan batasan cemaran hidrokuinon yang ditetapkan pemerintah, yaitu sebesar $2 \%$. Persentase kadar hidrokuinon masingmasing sampel diperoleh sebesar 0,0053\%, 0,0009\%, 0,0107\%, 0,0204\%, 0,0033\%, 0,0150\%, 0,0331\%, 0,0174\%, 0,0314\%, $0,0286 \%, 0,0093 \%$ dan $0,0023 \%$. Dengan demikian, analisis kuntitatif kadar hidrokuinon pada seluruh sampel yang digunakan dalam penelitian ini memberi hasil kadar hidrokuinon pada rentang 0,0009-0,0331\%. Kadar hidrokuinon tertinggi terdeteksi pada sampel kode G, yaitu sebesar $0,0331 \%$. Hasil penelitian ini menunjukkan bahwa secara keseluruhan, baik yang memiliki nomor registrasi BPOM maupun yang tidak memiliki nomor registrasi BPOM memiliki kadar hidrokuinon dalam sampel masih dalam batas aman, karena kadar hidrokuinon terdeteksi $<2 \%$. 


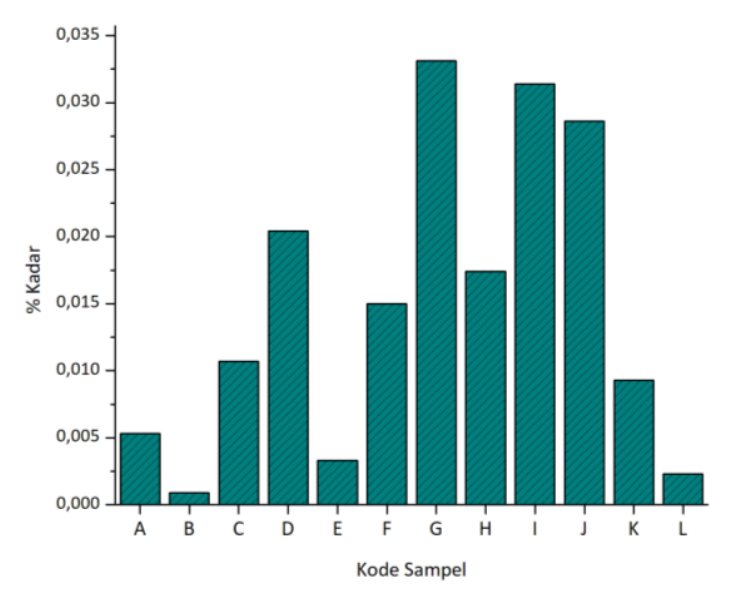

Gambar 2. Diagram Kadar Hidrokuinon dalam Sampel Krim Pemutih Wajah

Tabel 1. Hasil Analisis Kuantitatif Kandungan Hidrokuinon pada Krim Pemutih Wajah

\begin{tabular}{|c|c|c|}
\hline Sampel & Absorbansi & Kadar (\%) \\
\hline A & 0,079 & 0,0053 \\
\hline B & 0,016 & 0,0009 \\
\hline C & 0,163 & 0,0107 \\
\hline D & 0,309 & 0,0204 \\
\hline E & 0,051 & 0,0033 \\
\hline F & 0,227 & 0,0150 \\
\hline G & 0,476 & 0,0331 \\
\hline H & 0,267 & 0,0174 \\
\hline I & 0,450 & 0,0314 \\
\hline J & 0,409 & 0,0286 \\
\hline K & 0,138 & 0,0093 \\
\hline L & 0,036 & 0,0023 \\
\hline
\end{tabular}

Penelitian ini memberikan hasil yang serupa dengan penelitian yang dilakukan oleh Adriani dan Safira [18], dimana Adriani dan Safira melakukan penelitian mengenai analisis kadar hidrokuinon pada krim pemutih wajah racikan dokter yang beredar di klinik kecantikan di Banda Aceh. Penelitian tersebut memberikan persentase kadar hidrokuinon kurang dari $2 \%$, yakni pada kisaran kadar 0,000058-0,001188\% [18]. Kesimpulan yang sama dengan penelitian yang dilakukan oleh Agorku et al. [19] yang memberi hasil 0,243 $\pm 0,385 \%$ terhadap kadar hidrokuinon dalam sampel krim pemutih kulit. Penelitian yang telah dilakukan oleh Dian et al. [25] dengan sampel krim pemutih wajah dan didapat hasil sampel positif mengandung hidrokuinon dengan kadar tertinggi 0,35\%, selanjutnya penelitian yang telah dilakukan oleh Nurfitriani et al. [26] dengan sampel krim pemutih wajah dan di dapat hasil sampel positif mengandung hidrokuinon yaitu sampel A dengan kadar 1,07\%, sampel F 1,34\%, sampel $\mathrm{N} 1,34 \%$ dan sampel O 2,74\%.

Dari penelitian yang telah dilakukan dapat disimpulkan bahwa ditemukan adanya kandungan hidrokuinon pada krim pemutih wajah yang beredar di wilayah Surabaya Pusat dan Surabaya Utara dan masih dalam 
batas aman. Untuk penggunaan harian bisa digunakan tidak lebih dari 6 bulan, mengingat efek samping yang ditimbulkan. Dalam hal ini konsumen harus lebih berhatihati dalam memilih produk kosmetik terutama pada krim pemutih wajah.

\section{Kesimpulan}

Analisis kuantitatif kandungan hidrokuinon pada sampel krim pemutih wajah yang beredar di wilayah Surabaya Pusat dan Surabaya Utara menunjukkan bahwa seluruh sampel krim pemutih pada penelitian ini mengandung hidrokuinon, dan kadar tertinggi hidrokuinon diperoleh pada sampel G dengan perolehan kadar hidrokuinon sebesar 0,0331\%, dan secara keseluruhan kadar hidrokuinon pada sampel yang digunakan dalam penelitian ini tidak melebihi batas kadar hidrokuinon yang ditetapkan BPOM, yaitu tidak lebih dari $2 \%$.

\section{Daftar Pustaka}

[1] Z.D. Draelos, "The Cosmeceutical Conundrum," Journal of Cosmetic Dermatology, 4(3), 149-150. 2005.

[2] D. Arifiyana and MA. H. F. Fernanda, "Analisis Kualitatif dan Kuantitatif Cemaran Logam Berat Timbal $(\mathrm{Pb})$ dan Kadmium (Cd) pada Produk Kosmetik Pensil Alis Menggunakan
Spektrofotometer Serapan Atom (SSA)," Journal of Research and Technology, Vol. 4 No. 1, Juni. 2018.

[3] E. N. Glenn, "Yearning for Lightness: Transnational Circuits in the Marketing and Consumption of Skin Lighteners", Gender \& Society, 22(3), 281-302, 2008.

[4] J.L. Rondilla and P. Spickard, "Is Lighter Better? Skin-tone Discrimination among Asian Americans," Lanham, MA: Rowman \& Littlefield Newyork, 2007.

[5] I. Perry, "Buying White Beauty," Cardozo J. Law Gend., 12:579-607, 2006.

[6] M. Ashikari, "Cultivating Japanese Whiteness: The 'Whitening' Cosmetics Boom and The Japanese Identity", J. Mat. Cult., 10:73-91, 2005.

[7] Y. M. Olumide, A. O. Akinkugbe, D. Altraide, T. Mohammed, N. Ahamefule, S. Ayanlowo, C. Onyekonwu and N. Essen, "Complications of Chronic Use of Skin Lightening Cosmetics", International Journal of Dermatology, 7, 344-353, 2008.

[8] Z.D. Draelos, "Skin Lightening Preparations and the Hydroquinone 
Controversy," Dermatol Ther., 20 (5): 308-13, Sep-Oct. 2007.

[9] S. Gul, A. Monazzam, H. Rashid and S. M. Ali, "Hidden Killers for Women: Mercury, Steroids and Hydroquinone in Skin Whitening and Bleach Creams," Journal of Pharmacy and Pharmaceutical Sciences, Volume 2, Issue 1, 09-17, June. 2014.

[10]K. Yoshimura, K. Tsukamoto, M. Okazaki, V.M. Virador, T-C Lei, Y. Suzuki, G. Uchida, Y. Kitano, K. Harii K, "Effects of All-trans Retinoic Acid on Melanogenesis in Pigmented Skin Equivalents and Monolayer Culture of Melanocytes,” J. Dermatol Sci., 27:6875, 2001.

[11]P. Joseph, A.J.P. Klein-Szanto, A.K. Jaiswal, "Hydroquinones Cause Specific Mutations and Lead to Cellular Transformator and in vivo Tumorgenesis," $\mathrm{Br}$ J. Cancer, 78(3):312-320, 1998.

[12]D.H. Hutson, B.J. Dean, T.M. Brooks, G. Hudson-Walker, "Genetic Toxicology Testing of 41 Industrial Chemicals," Research, 153:57-77, 1999.

[13]Aldrich, "Catalog/Handbook of Fine Chemicals," Aldrich Chemical
Company, Milwaukee, WI, p 235, 1990.

[14]Badan Pengawas Obat dan Makanan, "Keputusan Kepala Badan Pengawas Obat dan Makanan Republik Indonesia No.KH.00.01.432.6081 tentang Kosmetik Mengandung Bahan Berbahaya dan Zat Warna yang Dilarang,” Jakarta, 2007.

[15] Irnawati, M. H. Sahumena, W. O. N. Dewi, "Analisis Hidrokuinon pada Krim Pemutih Wajah dengan Metode Spektrofotometri UV-Vis," PHARMACON Jurnal Ilmiah FarmasiUNSRAT, Vol. 5, No. 3, 2016.

[16]K. W. Sarah, "Analisis Hidrokuinon dalam Sediaan Krim Malam "CW1" dan "CW2" dari Klinik Kecantikan "N" dan "E" di Kabupaten Sidoarjo," Calyptra: Jurnal Ilmiah Mahasiswa Universitas Surabaya, Vol. 3 No. 2, 2014.

[17]D. W. Astuti, H. R. Prasetya, D. Irsalina, "Identifikasi Hidroquinon pada Krim Pemutih Wajah yang Dijual di Minimarket Wilayah Minomartani, Yogyakarta," Journal of Agromedicine and Medical Sciences, Vol. 2 No. 1, 1319, 2016.

[18]A. Adriani and R. Safira, "Analisa Hidrokuinon dalam Krim Dokter secara 
Spektrofotometri UV-Vis," Lantanida

Journal, Vol. 6 No. 2, 103-202, 2018.

[19]E. S. Agorku, E. E. Kwaansa- Ansah,

R. B. Voegborlo, P. Amegbletor and F.

Opoku, "Mercury and Hydroquinone

Content of Skin Toning Creams and

Cosmetic Soaps, and the Potential

Risks to the Health of Ghanaian

Women," SpringerPlus, 5:319, 2016.

[20] A. M. Htet, E. E. Thin, M. M. Saw, S.

Win, "Chemical analysis of

hydroquinone and retinoic acid contents

in facial whitening creams," Asian

Journal of Pharmaceutical Sciences 11, 89-90, 2016.

[21]E. Rahmayuni, Harmita, H. Suryadi, "Development and Validation Method for Simultaneous Analysis of Retinoic Acid, Hydroquinone and Corticosteroid in Cream Formula by High-

Performance Liquid Chromatography,"

Journal of Applied Pharmaceutical

Science Vol. 8(09), pp 087-092, 2018.

[22]Z. Moldovan, D. E. Popa, I. G. David,

M. Buleandra, and I. A. Badea, “A

Derivative Spectrometric Method for
Hydroquinone Determination in the

Presence of Kojic Acid, Glycolic Acid, and Ascorbic Acid," Journal of

Spectroscopy, Article ID 6929520, 2017, https://doi.org/10.1155/2017/6929520.

[23] M. R. Siddiqui, Z. A. AlOthman, and N. Rahman, "Analytical techniques in pharmaceutical analysis: a review," Arabian Journal of Chemistry, 2013.

[24]A. Rohman, "Kimia Farmasi Analisis. Cetakan I," Penerbit Pustaka Pelajar, Yogyakarta, 2007.

[25]L. Dian, Cikra, "Penetapan Kadar Hidrokuinon pada Krim Pemutih Wajah A dan B dengan Metode Kolorimetri," Skripsi, Fakultas Farmasi Institut Ilmu Kesehatan Bhakti Wiyata, Kediri, 2015. [26]S. Nurfitriani, G. Hadisoebroto, S. Budiman, “Analisis Penetapan Kadar Hidrokuinon pada Kosmetik Krim Pemutih yang Beredar di Beberapa Tempat di Kota Bandung," Seminar Nasional Farmasi (SNIFA) UNJANI. ISBN : 978-602-73060-1-1, 2015. 